\title{
Elephantiasis nostras verrucosa as a manifestation of morbid obesity
}

\author{
Irma Margarita Pérez-Rodríguez, Jorge Ocampo-Garza, Juana Irma Garza-Chapa, \\ Jorge Ocampo-Candiani
}

Hospital Universitario "Dr. José Eleuterio González"

Universidad Autónoma de Nuevo León, Monterrey, Nuevo León, Mexico

\section{Correspondence to} Dr Jorge Ocampo-Candiani, jocampo2000@yahoo.com.mx

Accepted 4 November 2014

\section{DESCRIPTION}

A 48-year-old man with morbid obesity was evaluated for atrial fibrillation. He had a history of abdominoplasty and had been bedridden since the procedure. His current weight was $394 \mathrm{~kg}$ and his previous weight $567 \mathrm{~kg}$. He presented a chronic disseminated dermatosis on both legs and abdomen, characterised by oedema, hyperpigmentation, hyperkeratosis and a verrucous aspect (figure 1). A skin biopsy showed hyperkeratosis, papillomatosis, proliferation and dilation of blood vessels and lymphatics, dermal fibrosis, haemosiderin deposition and fat lobules separated by thick fibrous septa with elongated fibroblasts. He died days after admission from heart complications and sepsis.

Obesity is a worldwide epidemic, a major public health problem and its prevalence is increasing. It is responsible for a variety of physiological skin changes.

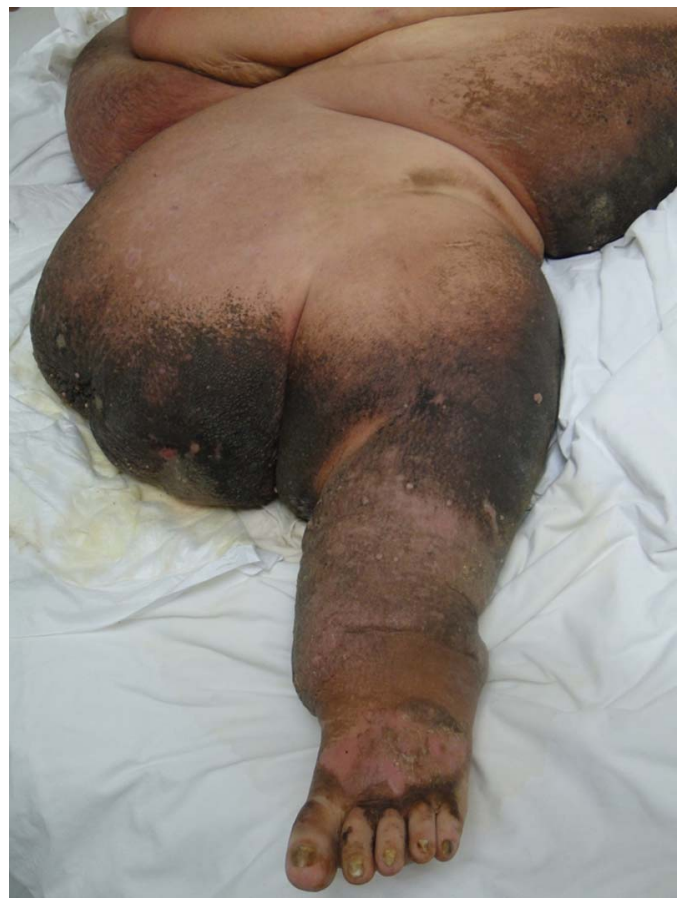

Figure 1 A case of Elephantiasis Nostras Verrucosa in a young man. This image shows oedema, hyperpigmentation, hyperkeratosis and a verrucous aspect involving legs and abdomen.
Elephantiasis nostra verrucosa (ENV) is a rare set of cutaneous manifestations associated with chronic lymphoedema. ${ }^{1}$ Multiple factors contribute to its origin, but its exact pathogenesis is unknown. Bacterial infections, malignancy, lymphangiomas, surgery, trauma, postradiation lymphatic fibrosis, obesity and chronic venous stasis are related to its development. In all of these conditions, chronic lymphatic obstruction and oedema cause accumulation of interstitial fluid, which induces fibroblast proliferation, and increases susceptibility to infection and inflammation, with subsequent skin and lymphatic fibrosis.

Treatment focuses on reducing lymphostasis and preventing recurrent infection. ${ }^{2}$ Skin changes are chronic and progressive, and management in advanced stages is often unsatisfactory, therefore it is important to recognise this condition in the early stages. In this patient, morbid obesity and chronic venous stasis were the main causal factors of ENV.

\section{Learning points}

- Obesity is a major health problem and is related with many physiological skin changes resulting in different skin diseases.

- Elephantiasis nostra verrucosa is a rare entity related to chronic lymphoedema, which can present in association with obesity.

- Owing to its chronicity and progression, early recognition and treatment of this entity is crucial to achieve a more satisfactory result.

Contributors IMP-R was involved in the writing and data analysis. JO-G was involved in the writing and preparing figures. $J \mid G-C$ was involved in the literature search and preparing figures. $\mathrm{JO}-\mathrm{C}$ was involved in the literature search and final review.

Competing interests None.

Patient consent Obtained.

Provenance and peer review Not commissioned; externally peer reviewed.

\section{REFERENCES}

1 Dean SM, Zirwas MJ, Horst AV. Elephantiasis nostras verrucosa: an institutional analysis of 21 cases. J Am Acad Dermatol 2011;64:1104-10.

2 Yosipovitch G, DeVore A, Dawn A. Obesity and the skin: skin physiology and skin manifestations of obesity. J Am Acad Dermatol 2007:56:901-6. 
Copyright 2014 BMJ Publishing Group. All rights reserved. For permission to reuse any of this content visit http://group.bmj.com/group/rights-licensing/permissions.

BMJ Case Report Fellows may re-use this article for personal use and teaching without any further permission.

Become a Fellow of BMJ Case Reports today and you can:

- Submit as many cases as you like

- Enjoy fast sympathetic peer review and rapid publication of accepted articles

- Access all the published articles

- Re-use any of the published material for personal use and teaching without further permission

For information on Institutional Fellowships contact consortiasales@bmjgroup.com

Visit casereports.bmj.com for more articles like this and to become a Fellow 